\title{
Wychowanie obywatelskie w percepcji katolickiej doktryny wychowawczej Drugiej Rzeczypospolitej prezentowane na łamach „Miesięcznika Katechetycznego i Wychowawczego" (1918-1939)
}

\section{Wprowadzenie}

Zamierzeniem niniejszego opracowania jest próba zaprezentowania, w jakich kategoriach i wymiarach teoretycy i praktycy wychowania katolickiego dwudziestolecia międzywojennego postrzegali wychowanie obywatelskie. Ograniczono się przy tym do charakterystyki ich stanowiska przedstawionego na łamach „Miesięcznika Katechetycznego i Wychowawczego"1, uznawanego współcześnie za

* Dr, Katedra Dydaktyki i Historii Wychowania, Wydział Nauk Społecznych, Uniwersytet Warmińsko-Mazurski, 10-725 Olsztyn, ul. Prawocheńskiego 13.

1 „Miesięcznik Katechetyczny i Wychowawczy” [dalej: MKiW] (1911-1939) to czasopismo poświęcone sprawom nauczania i wychowania religijnego, ukazujące się od roku 1911 i będące w pewnym sensie kontynuacją „Dwutygodnika Katechetycznego” (1897-1910). Wydawane było najpierw we Lwowie, a od połowy 1931 r. w Warszawie. Początkowo poruszano w nim głównie zagadnienia dotyczące katechezy szkolnej, a także wychowania, historii filozofii, teologii, apologetyki, archeologii, literatury współczesnej czy problematyki narodowo-patriotycznej. Od 1921 r. nadrzędne miejsce zajęły kwestie związane z katechizacją, pedagogiką, psychologią, dydaktyką religijną i duszpasterstwem szkolnym. Wśród autorów artykułów zamieszczanych na łamach MKiW w latach 1918-1939 warto wspomnieć: Zygmunta Bielawskiego, Franciszka Błotnickiego, Józefa Boczara, Jana Ciemniewskiego, Nikodema Cieszyńskiego, Jana Czuja, Franciszka Gabryla, Walentego Gadowskiego, Michała Godlewskiego, Wincentego Granata, Leona Heyke, Józefa Jałowy, Mateusza Jeża, Franciszka Koniecznego, Janinę Kotarbińską, Kazimierza Thullie, Jacka Woronieckiego, Barbarę Żulińską. Zob. Od Redakcji, MKiW 1931, z. 6-7, s. 241-242; W. G a d o w s k i, Z historii „Dwutygodnika Katechetycznego”, MKiW 1936, z. 4, s. 149-158; R. N i p a r k o, „Miesięcznik Katechetyczny i Wychowawczy” 1911-1939. Bibliografia zawartości, Poznań 2000, s. 17-22; P. K r ól i k o w s k i, „Miesięcznik Katechetyczny i Wychowawczy", [w:] Encyklopedia Katolicka, red. S. W i l k, E. Z i e m a n n i in., t. XII, Lublin 2008, s. 911-912. 
główne czasopismo pedagogiki katolickiej tamtego okresu². Przed poddaniem analizie artykułów, w których odnoszono się do interesującego mnie zagadnienia nieodzowne stało się zgłębienie dwóch problemów. Po pierwsze przyjrzenie się, jak w Drugiej Rzeczypospolitej rozumiano wychowanie obywatelskie. Po drugie zaś poznanie istoty katolickiego nurtu w pedagogice lat 1918-1939. Konsekwentnie, one też, dla klarowności podjętych rozważań, zostały włączone w treść niniejszego opracowania i stanowią swego rodzaju wstęp, ale na tyle istotny, że przybierają formę dwóch zagadnień, potraktowanych poniżej jako jego odrębne części.

\section{Wychowanie obywatelskie dwudziestolecia międzywojennego}

Zdaniem Mikołaja Kozakiewicza, w wieku XX państwa obejmowały swoją troską sprawę wychowania dobrego obywatela, postrzeganego w kategoriach dobrego obywatela „państwa-narodu”3. Dotyczyło to również Drugiej Rzeczypospolitej. Już jej pierwszy rząd z Jędrzejem Moraczewskim na czele zapewniał, w odezwie skierowanej do narodu 19 listopada 1918 r., iż jego istotnym zadaniem będzie budzenie w społeczeństwie ducha obywatelskiego i poczucia odpowiedzialności za losy państwa ${ }^{4}$. Konsekwentnie więc w programie oświatowym ówczesnego ministra oświaty Ksawerego Praussa wychowanie obywatelskie zajęło uprzywilejowaną pozycję. Szkoła miała według niego „wychowywać młode pokolenie Polaków, przepojonych duchem obywatelskim, obeznanych dokładnie z ziemią ojczystą, jej tradycją, zasobami i gospodarką, obywateli przygotowanych i chętnych do pracy twórczej na wszystkich polach życia dla dobra Ojczyzny i współobywateli" 5 . Starano się przy tym, aby wychowanie obywatelskie stanowiło składnik szeroko pojętego wychowania ${ }^{6}$, czyli łączono je z wychowaniem narodowym, państwowym, patriotycznym, społecznym czy moralnym, zaś

${ }^{2}$ Prof. Alina Rynio, ukazując potrzebę kontynuacji badań nad katolicką myślą pedagogiczną w Polsce w latach 1918-1939, określa „Miesięcznik Katechetyczny i Wychowawczy” jako główne czasopismo pedagogiki katolickiej w okresie międzywojennym. Zob. A. R y n i o, Potrzeba kontynuacji badań nad bogactwem katolickiej myśli pedagogicznej w Polsce w latach 1918-1939, [w:] Katolicka a liberalna myśl wychowawcza w Polsce w okresie międzywojennym - zagadnienia wybrane, red. E. W a I e w a n d e r, Lublin 2000, s. 487.

${ }^{3}$ M. Ko z a k i e w i c z, O nowym pojęciu „państwa” i „obywatela”, [w:] Demokracja a oświata, kształcenie $i$ wychowanie, red. H. K w i a t k o w s k a, Z. K w i e c i ń s k i, Toruń 1996, s. 61.

${ }^{4}$ W. J a m r o ż e k, Wychowanie obywatelskie w okresie Drugiej Rzeczypospolitej (geneza i rozwój), [w:] Wychowanie obywatelskie. Studium teoretyczne, porównawcze i empiryczne, red. Z. M e I o s i k, K. P r z y s z c z y p k o w s ki, Toruń-Poznań 1998, s. 72.

${ }^{5}$ F. A r a s z k i e w i c z, Wychowanie obywatelskie w okresie Drugiej Rzeczypospolitej, „Wychowanie Obywatelskie" 1971, nr 4, s. 14.

${ }^{6}$ M. I wa n icki, Wychowanie narodowościowo-obywatelskie (zarys problematyki), Siedlce 1992, s. 86. 
w praktyce szkolnej jego elementy najbardziej obecne były na lekcjach nauki o Polsce współczesnej, języka polskiego i historii ${ }^{7}$.

Krzysztof Jakubiak stwierdza, iż w dwudziestoleciu międzywojennym, „ideały obywatelskie oraz wartości i cele wychowawcze z tymi ideałami związane, odnosiły się najczęściej do stosunku i powinności obywatela względem narodu lub państwa. Tym samym stawały się częścią składową ideologii, nazywanych wychowaniem narodowym lub państwowym"8. Zaznacza on jednocześnie, iż cechy wzoru obywatela w obu tych ideologiach były bardzo podobne, a różniły się przede wszystkim podmiotem odniesienia obowiązków obywatelskich do narodu lub państwa, traktowanych jako najwyższa wartość, a także tradycjami ideowymi, stanowiącymi ich korzenie ${ }^{9}$.

Idea wychowania obywatelskiego w duchu narodowym zaczęła zaznaczać swoją obecność w Drugiej Rzeczypospolitej w początkach 1919 r., po upadku „Iudowego” rządu J. Moraczewskiego. Duże wpływy zdobyła wówczas Narodowa Demokracja $^{10}$, która do przewrotu Józefa Piłsudskiego w maju 1926 r. nie tylko wiodła prym na arenie życia politycznego, ale nadawała również ton działalności edukacyjnej, wprowadzając do oświaty lansowane przez siebie wychowanie narodowe $^{11}$.

Endecka ideologia wychowania narodowego skrystalizowała się na przełomie XIX i XX w., w sytuacji, kiedy naród polski będący przedmiotem, a nie podmiotem działalności politycznej państw zaborczych walczył o zachowanie swoich tradycji i odrębności. Narodziny pedagogiki narodowej związane są z powstaniem w 1887 r. Ligi Polskiej pojmującej ideę narodu jako jedność organiczną i propagującej wzór Polaka-człowieka aktywnego. Głównym ideologiem obozu narodowego był Roman Dmowski ${ }^{12}$, który zaprezentował wzór nowoczesnego patriotyzmu Polaka, polegający na przywiązaniu do narodowej indywidualności, języka, kultury i tradycji, a także odczuciu potrzeb narodu jako całości oraz zespoleniu się z jego interesami. Ówcześni pedagogiczni twórcy tej koncepcji, głównie Stanisław Prus-Szczepanowski ${ }^{13}$ (wzór Polaka obywatela-bohatera i pracownika) i Zygmunt Balicki ${ }^{14}$ (wzór Polaka żołnierza-obywatela), podkreślali, iż naczelnym zadaniem edukacji jest budzenie świadomości i identyfikacji narodowej. W czasie I wojny światowej, w obliczu realnego odzyskania przez Polskę wolności, podkreślano

\footnotetext{
${ }^{7}$ W. J a m ro ż e k, Wychowanie obywatelskie..., s. 72, 77.

${ }^{8} \mathrm{~K}$. Jak u biak, Idea wychowania obywatelskiego w polskiej myśli pedagogicznej przełomu XIX i XX wieku oraz okresu II Rzeczypospolitej, „Chowanna” 1998, t. 2 (11), s. 62.

9 Tamże, s. 63.

${ }^{10}$ Nazwa Narodowa Demokracja, obóz narodowy (w skrócie: endecja) oznacza obóz polityczny, który głosił nacjonalizm, a więc uznawał naród za naczelną wartość i dobro, zaś interesy narodu za nadrzędny wskaźnik poczynań społeczno-politycznych. Zob. S. R u d n i c k i, Narodowa Demokracja 1893-1939, [w:] Z dziejów Drugiej Rzeczypospolitej, red. A. G a r l i c k i, Warszawa 1986, s. 225-247.

${ }^{11}$ K. Trze bi a to w s ki, Szkolnictwo powszechne w Polsce w latach 1918-1932, WrocławWarszawa-Kraków 1970, s. 150.

${ }^{12}$ R. D m o w s k i, Myśli nowoczesnego Polaka, Florencja 1903.

${ }_{13}$ S. S z c z e p a n o w s k i, Aforyzmy o wychowaniu, Lwów 1901; t e n ż e, Myśli o odrodzeniu narodowym, Lwów 1903.

${ }^{14}$ Z. B a li c k i, Egoizm narodowy wobec etyki, Lwów 1902; t e n ż e, Zasady wychowania narodowego, Warszawa 1909.
} 
zasadność przewartościowania psychiki polskiej, co miałoby się odbywać poprzez rozwijanie zalet i zwalczanie wad narodowych (T. Grabowski ${ }^{15}$, Tadeusz Łopuszański ${ }^{16}$, ks. Jan Gralewski ${ }^{17}$ ), a także ukazywano, iż wzorem ideału wychowania narodowego w niepodległej Polsce powinien być Polak obywatel-twórca ${ }^{18}$ (Irena Pannenkowa ${ }^{19}$, Władysław Marian Borowski20).

W odradzającej się Polsce endecja podkreślała, że fundamentem moralnej siły narodu powinno być wychowanie religijne, narodowe i obywatelskie, stąd duch narodowo-chrześcijański stanowił wykładnik głoszonego przez nią ideału obywatela charakteryzującego się głęboką religijnością, miłością Ojczyzny, poczuciem odpowiedzialności, honoru i godności narodowej21. Pedagogiczne podłoże tego ideału przedstawił Lucjan Zarzecki ${ }^{22}$, który określił naród jako swoistą strukturę duchową, rodzaj osobowości zbiorowej, przewyższającej jednostkę i mogącej żyć bez państwa. Państwo reprezentowało według niego „moc wykonawczą narodu” i „środek życia narodu”. Wyłonił on wzór robotnika-obywatela, który będzie dobrze przygotowany do pracy oraz gotowy do oddania się na służbę narodowi, odznaczający się zapałem, energią duchową, wiarą w siebie i własne siły. Uzasadniał, iż wychowanie obywatelskie powinno być osadzone na tradycji narodowej, a czerpiąc z niej ma być przede wszystkim zwrócone ku przyszłości narodu. W latach dwudziestych, a szczególnie w okresie tzw. „rządów sejmu”, wychowanie obywatelskie w duchu narodowym o takim właśnie obliczu funkcjonowało jako oficjalna wykładnia światopoglądowego wychowania społeczeństwa, również w edukacji szkolnej ${ }^{23}$.

Po przejęciu władzy przez Józefa Piłsudskiego w 1926 r. na arenę życia politycznego wkracza sanacja, która wprowadza do rzeczywistości oświatowej ideał wychowania obywatelskiego w duchu państwowym, określanym mianem wychowania państwowego lub obywatelsko-państwowego. Ten ideał wychowania zaprezentowany został przez J. Piłsudskiego szerokiemu gremium społecznemu już w pierwszych latach niepodległej Polski, wyzwolonej spod ponad 120-let-

15 T. Grabowski, Zasady wychowania narodowego i pogląd na nie w dobie dzisiejszej, „Przegląd Oświatowy” 1918, s. 3-13.

${ }^{16}$ T. Ł o p u s z a ń s k i, Zagadnienie wychowania narodowego, „Przegląd Pedagogiczny” 1918, s. $129-143$.

17 J. G r a l e w s k i, Zadania wychowawcze szkoły narodowej w Polsce, „Wychowanie w Domu i Szkole" 1915, s. 634-643.

${ }^{18}$ C. M a jore k, Historyczne źródła teorii wychowania obywatelsko-państwowego w Polsce doby międzywojennej, [w:] Edukacja historyczna i obywatelska młodzieży w Polsce odrodzonej 19181939, red. J. M a t e r n i c k i, Warszawa 1987, s. 15-19; K. J a k u b i a k, Idea wychowania obywatelskiego..., s. 64-66; W. J a m r o ż e k, Wychowanie obywatelskie..., s. 69-71.

${ }^{19}$ I. P a n n e n k o w a, Myśli o wychowaniu narodowym, Lwów 1918.

${ }^{20}$ M. B o r o w s k i, Ogólne zarysy wychowania narodowego, Lublin-Warszawa 1918.

${ }^{21}$ F. Araszkiewicz, Ideały wychowawcze Drugiej Rzeczypospolitej, Warszawa 1978, s. 89-90.

${ }^{22}$ L. Z a r z e c k i, Charakter jako cel wychowania, Warszawa 1918; t e n ż e, Wychowanie narodowe, Warszawa 1926.

${ }^{23}$ M. J. Ż m i c h r o w s k a, Problematyka religijna i dydaktyczno-wychowawcza polskich czasopism dla dzieci i młodzieży szkolnej w latach 1918-1939, Warszawa 1992, s. 29-30; K. J a k u b i a k, Idea wychowania obywatelskiego..., s. 66-67; W. J a m r o ż e k, Wychowanie obywatelskie..., s. 72-74; S. W oło s z y n, Nauki o wychowaniu w Polsce w XX wieku, Kielce 1998, s. 155. 
niego okresu zaborów. Przedstawił on wówczas „nowy typ Polaka”24, mającego wprowadzić w życie wizję ojczyzny, w której panuje dobro i szczęście. Miał być to przede wszystkim człowiek czynu i pracy, promieniujący zapałem i energią, odznaczający się odwagą, honorem, męstwem, odpowiedzialnością, heroizmem i idealizmem ${ }^{25}$. Kierunek tego wychowania, który zrodził się na przełomie XIX i XX w., wyróżniał się humanitaryzmem, tolerancją wobec innych narodowości i wyznań oraz tęsknotą do własnej państwowości ${ }^{26}$. W dwudziestoleciu międzywojennym przyjął za cel wykształcenie świadomych swych praw i obowiązków twórczych obywateli Rzeczypospolitej Polskiej; uznających państwo za najważniejszą organizację społeczeństwa, zespalającą różne grupy i organizacje społeczne, ale zajmującą wobec nich centralną pozycję; wolnych od partykularyzmu wyznaniowego, klasowego, partyjnego czy narodowego; zdolnych do podporządkowania interesów indywidualnych czy społecznych interesom państwa; gotowych do ofiarnej i twórczej pracy na rzecz państwa; ugruntowanych w zakresie elementarnych wartości moralnych ${ }^{27}$. Osobowy ideał wychowawczy stanowiły postać i czyny Józefa Piłsudskiego ${ }^{28}$.

Głoszona przez sanację idea wychowania oparta na zasadach solidaryzmu państwowego zarysowana została na płaszczyźnie polityki oświatowej w sierpniu 1927 r. przez ministra WRiOP Gustawa Dobruckiego, w którego opinii „głównym zadaniem szkoły powinno być wychowanie młodego pokolenia na zdrowych fizycznie i moralnie oraz uspołecznionych i twórczych państwowo obywateli”29. Prawdziwa jednak oświatowa akcja sanacji rozpoczęła się w 1929 r., z chwilą objęcia teki ministra WRiOP przez Sławomira Czerwińskiego ${ }^{30}$, uznawanego za twórcę wychowania państwowego ${ }^{31}$, a w jego ramach wzoru obywatela bojownika-pracownika: człowieka zdyscyplinowanego, lojalnego, obowiązkowego, pełnego zapału do pracy, patrioty, entuzjastycznie nastawionego do państwa i wykonywanych obowiązków obywatelskich ${ }^{32}$.

${ }^{24}$ M. C y l k o w s k a-N o w a k, Edukacja obywatelska w szkołach Wielkiej Brytanii, Francji i Polski, [w:] Wychowanie obywatelskie. Studium teoretyczne, porównawcze i empiryczne, red. Z. M e l o sik, K. Przys zcz y p k ow ski, Toruń-Poznań 1998, s. 177. Por. H. P o h o ska, Wychowanie obywatelsko-państwowe, [w:] Encyklopedia wychowania, red. S. Ł e m p i c k i, W. G o t l i e b, B. S u ch o d ol s k i, t. 1, cz. II, Warszawa 1934.

${ }^{25}$ M. C y l k o w s k a-N o w a k, Edukacja obywatelska..., s. 177. Por. S. Ł e m p i c k i, Piłsudski jako wychowawca, Warszawa 1963.

${ }^{26}$ M. C y l k o w s k a-N o w a k, Edukacja obywatelska..., s. 177. Por. J. S z w e d, Drogowskazy obywatelskie w pismach i mowach J. Piłsudskiego, Wilno 1935.

${ }^{27}$ S. M a u e rs berg, Komu służyła szkoła w Drugiej Rzeczypospolitej?, Wrocław 1988, s. 26; M. J. Ż m i ch row s ka, Problematyka religijna..., s. 31; K. J a ku bi a k, Idea wychowania..., s. $67-68$.

${ }^{28}$ I. F i r e wi c z, O ideał obywatela państwowca w wychowaniu, [w:] Wychowanie obywatelskie młodzieży na wzorach bohaterstwa z doby zwycięskich walk o niepodległość Polski, Warszawa 1932, s. 4.

${ }_{29}$ Cyt. za: J. K ę s i k, Naród pod bronią. Społeczeństwo w programie polskiej polityki wojskowej 1918-1939, Wrocław 1998, s. 97.

${ }^{30}$ S. C z e r w iń s k i, O nowy ideał wychowawczy, Warszawa 1932.

${ }^{31}$ E. B r o d a c k a-A d a m o w i c z, Stanisław Łempicki (1886-1947) - człowiek i historyk, Toruń 2003, s. 151.

${ }^{32}$ M. F a I s k i, Koncepcja szkoły powszechnej i jej roli w ustroju szkolnictwa w okresie międzywojennym w Polsce, „Rozprawy z Dziejów Oświaty” 1958, t. 1, s. 207. 
Podstawą wychowania w jego ujęciu miał być kult ofiary i bohaterstwa na rzecz państwa uznawanego za najwyższe dobro.

Sanacyjną wizję wychowania obywatelskiego wprowadzał do oświaty również Janusz Jędrzejewicz ${ }^{33}$, szczególnie w okresie, kiedy piastował stanowisko ministra WRiOP. W jej duchu przeprowadził on w 1932 r. zasadniczą reformę szkolną, zgodnie z głoszonym przez siebie hasłem „zorganizowania społeczeństwa w państwo"34.

Do upowszechnienia i pogłębienia koncepcji wychowania państwowego przyczynili się także inni działacze oświatowi czy pedagodzy-teoretycy ${ }^{35}$. Wśród czołowych ideologów sanacji warto wspomnieć tu chociażby o Adamie Skwarczyńskim ${ }^{36}$ i Hannie Pohoskiej ${ }^{37}$. Uzasadnienie teoretyczne tego ideału odnajdujemy zaś w rozważaniach Kazimierza Sośnickiego ${ }^{38}$, Mieczysława Ziemnowicza ${ }^{39}$ czy Jana Stanisława Bystronia ${ }^{40}$. Zdaniem Stefana Wołoszyna dominował on do wybuchu II wojny światowej ${ }^{41}$, chociaż po śmierci J. Piłsudskiego, od połowy 1935 r., uległ modyfikacji w kierunku zaadaptowania elementów wychowania narodowego i katolickiego, zaś w obliczu zagrażającego niebezpieczeństwa utraty niepodległości - w kierunku narodowo-ojczyźnianym ${ }^{42}$.

\section{Katolicki ideał wychowawczy czasów Drugiej Rzeczypospolitej}

Jedną z ważnych ideologii pedagogicznych, obecnych w polskiej teorii i praktyce edukacyjnej okresu międzywojennego obok pedagogiki narodowej czy państwowej, była katolicka doktryna wychowawcza. Pedagogia katolicka Drugiej

\footnotetext{
33 J. J ę d r z e j e w i c z, Wychowanie państwowe, „Zrąb” 1930, t. 3.

${ }^{34}$ M. J. Ż m i c h r o w s k a, Problematyka religijna..., s. 33; W. J a m r o ż e k, Wychowanie obywatelskie..., s. 76.

${ }^{35}$ M. J. Ż m i c h r o w s k a, Problematyka religijna..., s. 33-35; W. J a m r o ż e k, Wychowanie obywatelskie..., s. 76-77; E. B r o d a c k a-A d a m o w i c z, Stanisław Łempicki..., s. 154-155.

${ }^{36}$ Nadał on rozważaniom nad wychowaniem państwowym kierunek pragmatyczny. Dotykał przy tym zagadnień ukierunkowanych głównie w stronę etyki i propagował wzór człowieka-pracownika. Zob. A. S k w a r c z y ń s k i, Myśl o nowej Polsce, Warszawa 1931; t e n ż e, Pod znakiem odpowiedzialności i pracy, Warszawa 1933.

${ }^{37}$ Podkreślała ona, iż najistotniejsze w wychowaniu, to kult dla państwa oraz cześć i miłość dla jego twórców, a także troska o jego rozwój. Dążyła do tego, aby przez wychowanie wyeliminować w państwie doktrynerstwo czy partyjniactwo. Zob. H. P o hos k a, Wychowanie obywatelsko-państwowe, Warszawa 1931; t e n ż e, Ideowe podstawy wychowania państwowego, „Zrąb” 1932, t. 12.

${ }^{38}$ K. S o ś n i c k i, Podstawy wychowania państwowego, Lwów-Warszawa 1933.

${ }^{39}$ M. Z i e m n o w i c z, Problemy wychowania współczesnego, Kraków 1927; t e n ż e, Wychowanie narodowe czy państwowe i jego istota, Kraków 1931.

40 J. S. B y s t r o ń, Wychowanie państwowe, „Kultura Pedagogiczna” 1933, z. 2; t e n ż e, Szkoła jako zjawisko społeczne, Warszawa 1939.

41 S. W oło s z y n, Nauki o..., s. 159.

${ }^{42}$ K. J a k u b i a k, Idea wychowania obywatelskiego..., s. 68; W. J a m r o ż e k, Wychowanie obywatelskie..., s. 80.
} 
Rzeczypospolitej określana była przez jej przedstawicieli przede wszystkim pedagogią autorytetu i miłości - autorytetu najwyższego, a więc autorytetu Boga, któremu podlegają na płaszczyźnie sumienia i wychowankowie, i wychowawcy zarówno w życiu teraźniejszym, jak i przyszłym³; pedagogią miłości zaś, z uwagi na to, że miłość Boga ku człowiekowi i miłość człowieka ku Bogu i bliźniemu jest osią religii katolickiej, a także miłością chrześcijańską, a więc oczyszczoną z pobłażliwości, egocentryzmu, naiwności, bezradności, fanatyzmu czy faryzeizmu ${ }^{44}$. Do jej głównych cech zaliczono głównie: humanitaryzm - personalizm, nadprzyrodzoność (wiarę i łaskę), uniwersalizm, charakter pozytywny oraz chrystocentryzm.

W humanitaryzmie odnajdujemy głównie poszanowanie godności ludzkiej w każdym człowieku, a także zachowanie i nienaruszalność celów indywidualnych oraz możność ich rozwoju. Uwypuklenie wartości człowieka i jego godności wynika $z$ faktu stworzenia człowieka na obraz i podobieństwo Boże oraz jego odkupienia. Jednak chociaż natura ludzka została ubóstwiona przez to, że Syn Boży stał się człowiekiem, to jednak człowiek zachował swą indywidualność ${ }^{45}$, wobec czego "Człowiek przez swą duszę nieśmiertelną jest wyższy ponad państwa i narody, ponad wszystkie królestwa świata i stosy złota w bankach"46. Personalizm katolicki w pedagogice wychodzi więc naprzeciw wychowaniu humanistycznemu, rozwojowi samodzielności, indywidualnemu traktowaniu wychowanka, rozbudzaniu w nim poczucia odpowiedzialności i honoru. Realizuje również przekonanie, że człowiek nie jest jedynie członkiem narodu, państwa, Kościoła itp., ale przede wszystkim jest osobą w wymiarze doczesnym i wiecznym ${ }^{47}$. Niemniej jest to tylko jedna strona humanitaryzmu katolickiego. Człowiek bowiem jako dziecko Boże powinien naśladować swego Ojca, a więc pracować nad urzeczywistnieniem Królestwa Bożego na ziemi. Dlatego też podstawą jego postępowania muszą być chrześcijańskie idee, dalekie od „kultu instynktów, [...] kultu nieskrępowanej wolności i niezależności od praw wyższego rzędu"48.

Drugą, przynależną pedagogii katolickiej cechą jest nadprzyrodzoność (wiara i łaska Boża działająca w Kościele Bożym i jego sakramentach). Przypomina ona, iż w wychowaniu nie wystarczy liczyć tylko na własne siły (ustalony program nauki, podręczniki, wiedzę osobistą, doświadczenie swoje i innych itd.), lecz przede wszystkim na „tajemnicę łaski Bożej nadprzyrodzonej, która leczy i uzdrawia duszę"49. Wobec tego wynika wręcz zobowiązanie korzystania ze środków nadprzyrodzonych w kształtowaniu charakteru, jak również postulat pokory, pojmowanej w kategoriach ducha obiektywizmu, a także religijnego i wyznaniowego charakteru szkoły ${ }^{50}$. Wnioskiem zaś praktycznym, wynikającym

${ }^{43}$ M. W ę g l e w i c z, Cechy znamienne pedagogii katolickiej, MKiW 1938, z. 1, s. 4.

44 Tamże, s. 5.

${ }^{45}$ W. G r a n a t, Katolicki ideał wychowawczy, MKiW 1936, z. 8, s. 326.

${ }^{46} \mathrm{Te} \mathrm{n}$ ż e, Zasady pedagogii katolickiej w świetle dogmatu odkupienia grzechu pierworodnego, MKiW 1939, z. 1-2, s. 32.

47 Tamże, s. 35

48 Te nż e, Katolicki..., z. 8, s. 328.

${ }^{49}$ M. W ę g l e wi c z, Cechy..., s. 5-6.

${ }^{50}$ W. G r a n a t, Zasady pedagogii katolickiej..., s. 40. 
z nadprzyrodzoności ideału katolickiego jest optymizm jako cecha i obowiązek życia katolickiego, ponieważ, jak podkreślał o. Jacek Woroniecki, „zły humor, narzekanie, zniechęcenie, pesymizm są to rzeczy, które w żaden sposób z duchem katolickim nie dadzą się pogodzić; na dnie ich tkwi zawsze brak ufności w opatrzność Bożą i podrażniona miłość własna"51.

Przez cechę nadprzyrodzoności pedagogika katolicka podkreśla, iż „nie możemy wychować człowieka, jeśli nie wychowamy dziecka Bożego", ponieważ „abyśmy mogli iść z ziemi ku niebu, musimy iść z Chrystusem z nieba ku ziemi i z Chrystusem z ziemi i przez ziemię ku niebu"52. Wynika to zaś z wiary Kościoła katolickiego, że istniejące w człowieku rozdarcie wewnętrzne, sprawiające że czyni on zło, którego nie chce, a którego korzenie tkwią w grzechu pierworodnym, przez który nastąpiła utrata dóbr nadprzyrodzonych (nadprzyrodzonej miłości, przyjaźni z Bogiem) i pierwotnej harmonii władz, może zostać zniwelowane przez zbawczą siłę łaski, płynącą z odkupienia Chrystusa ${ }^{53}$.

Kolejnym elementem wychowania katolickiego, wynikającym z faktu, że człowiek upadł, ale też został odkupiony przez Chrystusa przynoszącego wiarę i miłość, jest uniwersalizm. Jedną z jego właściwości jest konieczność objęcia kształceniem i wychowaniem każdego człowieka niezależnie od jego pochodzenia narodowego czy państwowego. Dobitnie zaznaczał to Pius XI, pisząc w encyklice O chrześcijańskim wychowaniu młodzieży54: „Co się tyczy zakresu wychowawczego posłannictwa Kościoła, to ono się rozciąga bez żadnego ograniczenia na wszystkie narody, stosownie do rozkazu Chrystusa: «Nauczajcie wszystkie narody» (Mt 25, 19)" "55. Drugą zaś cechą uniwersalizmu jest wychowanie całego człowieka, ponieważ cały człowiek upadł i cały został odkupiony. Wobec tego żadna dziedzina wychowania nie może być wyjęta spod działania łaski, co sprawia, iż pedagogika katolicka szanuje wszystkie działy wychowania z intencją uszlachetnienia ich przez łaskę. Wskazywał na to również Pius $X I^{56}$, zauważając, iż „Chrześcijańskie wychowanie obejmuje cały zakres ludzkiego życia fizycznego i duchowego, intelektualnego i moralnego, indywidualnego, rodzinnego i społecznego, nie żeby je w jakikolwiek sposób umniejszyć, ale żeby je podnieść, nim pokierować i udoskonalić, wedle przykładu i nauki Chrystusa"57.

Jak już wcześniej wspomniano, w ujęciu katolicyzmu człowiek ma osłabione władze moralne przez grzech pierworodny, lecz „przez Chrystusa został odkupiony i przywrócony do nadprzyrodzonego stanu przybranego dziecka Bożego"58. Ta wiara w uszlachetnienie natury człowieka i podniesienie jej do stanu nadprzyrodzonego stanowi cel prac wychowawczych Kościoła i nadaje pedagogii kato-

${ }^{51}$ Cyt. za: te n ż e, Katolicki..., z. 8, s. 338.

52 Te n ż e, Zasady pedagogii katolickiej..., s. 43.

${ }^{53}$ Te n ż e, Katolicki..., z. 8, s. 330.

${ }^{54}$ Te n ż e, Zasady pedagogii katolickiej..., s. 43-44.

${ }^{55}$ P i u s XI, Divini Illius Magistri, Rzym 1929, n. 25. [Numeracja na podstawie tekstu angielskiego zamieszczonego na stronie: www.vatican.va].

${ }^{56}$ W. G r a n a t, Katolicki..., z. 9, s. 373-380 i z. 10, s. 421-425; t e n ż e, Zasady pedagogii katolickiej..., s. 45-46.

${ }^{57}$ P i u s XI, Divini..., n. 95.

${ }^{58}$ Tamże, n. 58. 
lickiej kolejny istotny rys - pozytywny charakter, a przez to prowadzić może do uświęcenia życia społecznego, politycznego, gospodarczego czy umysłowego. Podstawą osiągnięcia tego celu jest przede wszystkim szukanie przez człowieka w każdej sferze życia Królestwa Bożego, przez co powstaje w nim energia duchowa przekształcająca jego naturę i wpływająca dobroczynnie na zmianę stosunków społecznych. Ten pozytywny charakter katolicyzmu przyczynił się zdaniem Wincentego Granata do stworzenia przez Kościół europejskiej kultury chrześcijańskiej przez uszlachetnienie życia indywidualnego i społecznego w rodzinach, państwach, filozofii, literaturze, malarstwie, architekturze ${ }^{59}$.

Ostatnim z przywołanych na początku, a jednoczenie najbardziej istotnym przymiotem katolickiego wychowania, jest chrystocentryzm, którego kluczem jest chrystocentryczna nauka katolicka, a więc powiązanie wszystkich dogmatów z Chrystusem Synem Bożym i Synem Człowieczym ${ }^{60}$. W konsekwencji - dla pedagogii katolickiej cele są wyznaczane przez Chrystusa żyjącego w Kościele i temu podporządkowane są zasady kształcenia i wychowania człowieka, który byłyby zdolny do tworzenia nowych dóbr kulturalnych i osiągania celów wyznaczonych przez wymogi społeczno-indywidualne ${ }^{61}$.

\section{Międzywojenna pedagogika katolicka wobec ówczesnego wychowania obywatelskiego}

Jakie stanowisko reprezentowała pedagogika katolicka wobec wyłaniającego i ewaluującego w Drugiej Rzeczypospolitej wychowania obywatelskiego? Analiza artykułów zamieszczonych w "Miesięczniku Katechetycznym i Wychowawczym” pozwala na stwierdzenie, iż jednomyślnie uznawano, że podstawę wychowania obywatelskiego powinno stanowić wychowanie religijne ${ }^{62}$.

Zaznaczano, iż wychowanie obywatelskie w szkole należy opierać na religii objawionej, która zapewnia stałe wartości i prawdy. Podkreślano wręcz, że jeśli państwowość polska chce oprzeć przyszłość narodu na wychowaniu, to musi uwzględnić fakt, iż „religia i odpowiedzialność społeczna wobec Boga - oto tło wszystkich poczynań pedagogicznych"63. Powoływano się przy tym na historyczną myśl i praktykę pedagogiczną. Przywołano m.in. Johna Locke’a, który będąc przedstawicielem szkoły liberalnej, uznawał potrzebę przekazania prawdziwego pojęcia o Bogu jako pierwszego fundamentu cnoty wzbudzanej w sercu dziecka ${ }^{64}$.

\footnotetext{
${ }^{59}$ W. G ra n a t, Katolicki..., z. 10, s. 425-430.

60 Tamże, s. 430-435.

${ }^{61}$ Te n ż e, Zasady pedagogii katolickiej..., s. 28.

62 T. D[ługosz], Przed Walnym Zebraniem, MKiW 1922, z. 11-12, s. 6; W. C z e c z o t t, Zadanie ks. prefekta w szkołach średnich, MKiW 1925, z. 6-7, s. 241.

${ }^{63}$ K. P i o trow s k i, Refleksje nad problemem wychowania z okazji dziesięciolecia encykliki papieża Piusa XI-go, MKiW 1939, z. 1-2, s. 16.

64 Tamże.
} 
Przypomniano też, że w przedmowie Ustaw Komisji Edukacji Narodowej twórcy wychowania narodowego dostrzegali potrzebę włączenia w jego nurt również religii. Pisali oni: „Nauczyciele, którzy się w rzeczonym stanie tworzyć i kształcić mają, w tym widoku uważani być powinni, jako jednej ze Rzeczypospolitej obywatele, przejęci świętością zamierzenia swego i urzędu tak wielkiej wagi: tym jedynie zabawieni, aby jak najdokładniej co do wiary świętej, czystych obyczajów, miłości Ojczyzny, znajomości praw narodowych i najużyteczniejszych w społeczności ludzkiej nauk wychowywali i doskonalili synów obywatelskich"65. Posiłkowano się również myślą Lucjana Zarzeckiego, który w książce $O$ wychowaniu narodowym ukazywał, iż ideał miłości Ojczyzny, ideał narodowy należy budować na religii, na miłości Boga, pisząc: „Nie masz racjonalnego systemu wychowania bez uwzględnienia pierwiastków religijnych, drzemiących na dnie duszy ludzkiej i we właściwej formie uzewnętrzniających się w danym społeczeństwie"66.

Stwierdzano, iż w wychowaniu obywatelskim pomocna może być nauka religii z uwagi na to, że może się ona przyczynić „do wychowania wzorowego obywatela kraju, któryby nie tylko znał swe obowiązki wobec państwa i społeczeństwa, ale je także w życiu sumiennie wykonywał" ${ }^{67}$. Przy przywoływaniu tej racji przypominano encyklikę Piusa XI O chrześcijańskim wychowaniu młodzieży wskazującego, iż celem wychowania chrześcijańskiego jest ukształtowanie chrześcijanina, który byłby najlepszym i najbardziej pożytecznym obywatelem ${ }^{68}$. Powołując się na rozważania Sylwiusza Antoniano, zauważał on, iż „Im bardziej rząd świecki zharmonizuje się z duchownym, i bardziej mu sprzyja i popiera go, tym bardziej przyczynia się do zachowania republiki. Albowiem podczas, gdy rządca kościelny, stosownie do swojego celu, stara się wyrobić dobrego chrześcijanina za pomocą powagi i środków duchownych, równocześnie siłą nieuniknionej konsekwencji wyrabia dobrego obywatela, jakim być powinien pod względem politycznym. Stąd to pochodzi, że w świętym, rzymskim katolickim Kościele, owym państwie Bożym, absolutnie to samo jest być dobrym obywatelem, co uczciwym człowiekiem. Zatem bardzo błądzą ci, co rozdzielają rzeczy tak bardzo ze sobą złączone, i co sądzą, że będą mogli mieć dobrych obywateli, za pomocą innych praw i na innych drogach, jak te, co sprzyjają wyrobieniu dobrego chrześcijanina"69.

Ks. Adam Gerstmann, idąc tym tropem, dowodził, iż cała działalność duszpasterska i wychowawcza katechetów wychodzi naprzeciw wychowaniu państwowemu, ponieważ przyczynia się do wychowania dobrych, uświadomionych i ofiarnych obywateli. Wynika to jego zdaniem z prostej zależności: „Im lepszych wychowamy katolików, tym lepszych będzie miała Polska obywateli, tym mniej pasożytów, wywrotowców i wrogów Państwa. Przecież prawdziwie chrześcijańskie wychowanie dąży do wyrobienia sumienia, poczucia odpowiedzialności za swe czyny przed Bogiem i ludźmi, miłości Boga i bliźniego, rodziny i Ojczyzny,

\footnotetext{
${ }^{65}$ Cyt. za: tamże, s. 16-17.

66 Cyt. za: tamże, s. 24.

67 J. G r o c h o c k i, Nauka religii a wychowanie państwowo-obywatelskie, MKiW 1931, z. 1, s. 5.

68 Tamże, s. 5-6; Z. C h o r o m a ń s k i, Wychowanie państwowe, MKiW 1933, z. 1, s. 34-35.

${ }^{69} \mathrm{P}$ i u s XI, Divini..., n. 54.
} 
posłuszeństwa, solidarności, karności, a zatem do tych cnót, które bezpośrednio służą dobru Państwa. A oparcie tych cnót na niezłomnym podłożu wiary i jej autorytecie nie osłabia [...] ich wartości, ale [...] zapewnia im stałość i odporność na zakusy wrogów Państwa i idei służby Państwu"70.

Zauważał przy tym, iż trafnie i głęboko kwestię związku religii i wychowania obywatelskiego przedstawił Fryderyk Wilhelm Foerster, stwierdzając w Wychowaniu obywatelskim: „Jest to wielkie złudzenie, wypływające z niedostatecznej znajomości natury ludzkiej, jeśli się sądzi, że rzeczywistą lojalność wobec Państwa, rzeczywiście głęboko zakorzenioną sumienność obywatelską oprzeć można na samej tylko politycznej świadomości, na samych tylko przyrodzonych dobrych skłonnościach człowieka, oraz na ich ożywieniu społeczno-etycznym. Bezmierną siłę ciążenia samolubstwa, przemożną rzeczywistość konkretnych korzyści pokonać jeno mogą potęgi Królestwa, które nie jest z tego świata. Przeciwspołeczna, przeciwpaństwowa miłość samego siebie, twardy upór samowoli, demoniczna potęga zła, szał rozpętanych namiętności - oto siły, którym tylko duchowa moc chrześcijaństwa sprostać zdoła. Obywatelskie zaś wychowanie bez uświęcenia i fundamentu kultury religijnej, wisi w powietrzu, stanowi sport dla głów próżnujących, złudzenie i marzenie bez żadnej prawdziwej twórczej mocy politycznej"71.

Podkreślano wręcz, iż katecheta może i powinien współpracować w dziele wychowania obywatelskiego ${ }^{72}$, podpowiadając, iż podstawowe wiadomości o państwie, jego zadaniach czy obowiązkach obywatelskich, można omawiać przy dogmatyce i etyce ${ }^{73}$. Dowodzono nawet, iż nauka religii katolickiej uwzględnia prawie całokształt obowiązków państwowo-obywatelskich. Po pierwsze, wychodząc z założenia, iż wszelka władza pochodzi od Boga, przekazuje ona szacunek wobec władzy państwowej. Po drugie, przy omawianiu IV przykazania Bożego przypomina o konieczności podjęcia obowiązków wobec państwa, a więc współdziałaniu dla dobra ogólnego, dla rozwoju i rozbudowy państwa poprzez należyte wykonywanie służby wojskowej i podjęcie obrony państwa w razie wojny, przez płacenie podatków czy korzystanie z przysługującego obywatelom prawa wyborczego. Po trzecie, uświadamia uczniów o ciążących na każdym z nich obowiązkach społecznych. Czyni to głównie przy omawianiu przykazania miłości bliźniego oraz przykazań Bożych od $\mathrm{V}$ do $\mathrm{X}$. Etyka katolicka ${ }^{74}$ zaś, z uwagi na fakt, że wychowanie społeczne stanowi naturalną część wychowania religijno-moralnego, opierając się na regule miłości i sprawiedliwości, nakłada na każdego obowiązek poszanowania siebie jako człowieka oraz poszanowania godności ludzkiej wobec drugich niezależnie od ich stanu społecznego (potępienie walki klas i demagogii), narodowości (potępienie kosmopolityzmu i skrajnego nacjonalizmu) czy wyznania (poszanowanie dla obcych przekonań religijnych ${ }^{75}$ ), a także

\footnotetext{
${ }^{70}$ A. G e r s t m a n n, O wychowaniu państwowym, MKiW 1935, z. 5, s. 222.

${ }^{71}$ Cyt. za: tamże, s. 222-223.

72 Tamże, s. 226.

73 Tamże, s. 223.

${ }^{74}$ Powołuje się tu m.in. na założenia etyki katolickiej ks. dr. Jana Ciemieniewskiego. Zob. J. C i e m i e n i e w s k i, Etyka katolicka, Lwów 1930.

${ }^{75}$ Według zasady św. Augustyna „In dubiis libertas, in necessariis unitas, in omnibus caritas" -
} 
poszanowania życia ludzkiego, rodziny, cudzej własności i czci oraz obowiązek pracy, oszczędności i odwagi cywilnej ${ }^{76}$.

Dodatkowo zaznaczano, iż nauka religii katolickiej wzmacnia wychowanie obywatelskie przez wskazywanie młodym wzorów ludzi prawdziwie religijnych i jednocześnie oddanych swojemu narodowi, krajowi, Ojczyźnie, a więc dobrych chrześcijan i obywateli państwa, m.in. sylwetki Abrahama, Mojżesza, Sędziów, Dawida, Jeremiasza, Machabejczyków, św. Augustyna, św. Bernarda, króla Władysława Jagiełły, króla Jana Sobieskiego, ks. Augustyna Kordeckiego, św. Stanisława Kostki, ks. Ignacego Skorupki ${ }^{77}$.

Przekonywano, że wpływ wychowawczy nauki religii w zakresie wychowania obywatelskiego jest niezwykle istotny, gdyż posługuje się nie tylko przyrodzonymi środkami potrzebnymi do wykonania powziętych postanowień obywatelskich, którymi posiłkują się też inne przedmioty, jak czuwanie nad sobą, zwalczanie swych wad, ćwiczenie się w posłuszeństwie, pilności, ale przede wszystkim charakterystycznymi dla religii środkami nadprzyrodzonymi - modlitwą, sakramentami świętymi, nabożeństwami, mszą świętą - dzięki którym obywatel będzie spełniał czynności obywatelskie nie z przymusu, ale poczucia własnej potrzeby moralnej ${ }^{78}$. Dzięki temu, że nadnaturalne środki wychowania, jakimi posługuje się religia służą nie tylko osiągnięciu wiecznego przeznaczenia, ale także stanowią narzędzie zrealizowania doczesnego celu wychowawczego „przez odniesienia zwycięstwa nad sobą, przez pokonanie niższego człowieka", stają się źródłem lepszego zrozumienia ideału wychowawczego Ojczyzny. Dzieje się to dzięki temu, że prawdy religijne podają człowiekowi wyższe, wznioślejsze pojęcie o życiu, co przekłada się na fakt, iż „ideał Ojczyzny staje się piękniejszy, bo czystszy, bo bardziej bezinteresowny, dobro jej pełniejsze i więcej wszechstronne"79. Poza tym - jak pisał ks. Stanisław Podoleński w Podręczniku pedagogicznym - „któż może skuteczniej uszlachetnić i wzmocnić wolę, jeśli nie sam jej Stwórca, znający dobrze ludzką słabość. Człowiek bez Boga, bez wiary w życie wieczne mógłby rzec sobie: Po cóż nam walczyć, czemu się przezwyciężać, czyż nie lepiej używać? Ale w świetle prawd wiecznych cała rzecz przedstawia się inaczej i daje silnego bodźca do pracy nad wyrobieniem woli i charakteru" 80 .

Niejednokrotnie podkreślano, iż w ramach troski o wychowanie obywatelskie obowiązkiem nauczycieli, w tym również katechetów jest wyrabianie w wychowankach nie tylko szlachetnych uczuć, ale przede wszystkim woli, z której może zrodzić się czyn ${ }^{81}$. Kształcenie woli i charakteru, to zdaniem autorów artykułów

w sprawach wątpliwych wolność, w sprawach koniecznych jedność, we wszystkim zaś miłość. Zob.

J. G r o c h o c k i, Nauka religii..., s. 8.

${ }^{76}$ Tamże, s. 6-8.

77 Tamże, s. 8; A. G e r s t m a n n, O wychowaniu..., s. 223.

${ }^{78}$ J. G r o c h o c k i, Nauka religii..., s. 9.

${ }^{79}$ K. Pi o trow ski, Refleksje..., s. 19.

${ }^{80}$ Cyt. za: J. W a c ła w s k i, Wola - jako czynnik wychowawczy, MWiK 1925, z. 6-7, s. 276.

${ }^{81}$ Z. Bielawski, Podstawy psychologiczne $w$ wychowaniu religijnym, MWiK 1921, z. 2 , s. 6-19; J. Wa cła w s ki, Wola..., s. 268-278; K. P i o trow s ki, Kilka słów o potrzebie opieki moralnej nad młodzieżą w wieku szkolnym, MWiK 1925, z. 10, s. 434, 441; A. G e r s t m a n n, O wychowaniu..., s. 220. 
zamieszczonych na łamach "Miesięcznika Katechetycznego i Wychowawczego" fundament wszelkiego wychowania, również tego, które ma ukształtować rasowego obywatela ${ }^{82}$, ponieważ - jak zaznaczał ks. Zygmunt Bielawski - powołując się na myśl Władysława Mariana Borowskiego - „W usposobieniu naszym [Polaków - A. Z.] daje się zauważyć pewna impulsywność i żywiołowość uczuć obok stanowczej skłonności do intelektualizmu, natomiast słabiej występuje zdolność do trwałego wysiłku, która zależy od stopnia rozwoju woli”83.

Ks. Jan Wacławski zauważał wręcz, że przyczyną wszelkich niepowodzeń narodu polskiego jest słabość woli, a w konsekwencji lęk przed podjęciem trwałego wysiłku, bierność, lekkomyślność i roztargnienie. Kształcenie woli rodzi zaś cierpliwość, umiejętność panowania nad sobą, samozaparcia się, poświęcenia, wytrwałości, przez które można wykorzenić każdą wadę: lenistwo, dumę, zarozumiałość, sobkostwo, egoizm, niestałość ${ }^{84}$. Jego zdaniem należy przy tym pamiętać o stosowaniu odpowiednich metod. W wychowaniu szkolnym przede wszystkim trzeba przyzwyczajać młodych do stanowczego posłuszeństwa. Mądry wychowawca, szanując u młodzieży samodzielność i swobodę do pewnego stopnia, musi domagać się od wychowanka spełniania rzetelnego poleceń i rozkazów roztropnych. Mądra, konsekwentna praca wychowawcza nie stworzy z dziecka manekina czy bezmyślnej chorągiewki, ale powoli wychowa człowieka-obywatela. Wychowawca nie powinien też pominąć przyzwyczajania codziennie młodzieży w życiu szkolnym czy domowym do cnoty prawdomówności, do punktualności, sumienności, porządku i schludnościes.

Powołując się na Barbarę Żulińską - która w Nauce moralności narodowej pisała, iż „człowiek, który umie milczeć, nie obmówi, nie skłamie, nie lży, nie bliźni, nie gdera, nie zdradzi tajemnicy, ale mówi tylko wtedy, gdy tego potrzebuje bliźni czy idea"86 - ks. J. Wacławski podkreślał, że baczną uwagę należy też poświęcić cnocie milczenia, w której zawiera się panowanie nad sobą, nad swoim językiem, tak skorym do stawiania wyroków na szkodę sławy i czci bliźniego ${ }^{87}$.

Jego zdaniem, wolę i charakter wyrabia również abstynencja - powstrzymywanie się od tytoniu, alkoholu, teatru, tańca, różnych „smakołyków”, a także skautowska idea, na którą, oprócz wspomnianej wstrzemięźliwości, składają się: altruizm, niesienie pomocy bliźniemu, codziennie spełniony jakiś dobry uczynek, umiłowanie Ojczyzny i przyrody rodzimeje. Zgodnie zaś z przysłowiem rzymskim: verba movent, exempla trahunt, tj. słowa poruszają, przykłady pociągają, roztropny wychowawca w pracy swej z młodzieżą nie powinien pomijać metody przywoływania jej czynów zbiorowych, instytucji i postaci, których niejednokrotnie hasłem były słowa: „Jak słodko i chwalebnie umierać za Ojczyznę” lub „Na ziemi

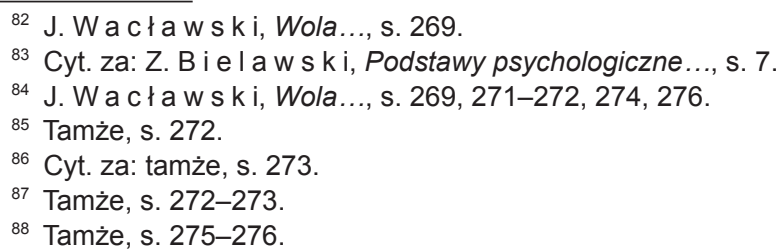


być Polakiem, to żyć bosko i szlachetnie". Wśród nich warto wspomnieć o Komisji Edukacji Narodowej, Konstytucji majowej, świętych Kościoła katolickiego czy prawdziwych patriotach (Stefan Czarniecki, Stanisław Żółkiewski, Jan Zamoyski, ks. Piotr Skarga, Tadeusz Czacki, Tomasz Zan, Adam Mickiewicz, Tadeusz Kościuszko, Romuald Traugutt, gen. Józef Haller, „Orlęta” Iwowskie) $)^{89}$.

W trosce o wychowanie obywatelskie przedstawiciele pedagogii katolickiej monitowali na łamach „Miesięcznika Katechetycznego i Wychowawczego” nie tylko o uwzględnienie w edukacji religii oraz kształcenia woli. Doceniając wartość przedmiotów humanistycznych, przekonywali, że nauka filologii klasycznej czy historii również pozytywnie wpływa na wyrobienie zmysłu praktycznego oraz cech dobrego obywatela, zatroskanego o dobro nie tylko swoje, ale też innych obywateli swojego kraju. Dla udowodnienia owych racji ks. Aleksander Pechnik przytoczył przykład angielskich szkół średnich, w których kształcenie odbywało się w oparciu o filologię klasyczną, a inteligencja tego kraju odznacza się praktycznością i kupieckim zmysłem, a także solidarną Wielkopolskę, w której w porównaniu $z$ innymi regionami kraju uczono znacznie więcej filologii ${ }^{\circ}$.

Wielu zauważało, iż kształtowaniu dobra ojczystego może służyć szczególnie literatura ojczysta, stąd konieczność podjęcia troski o jej jakość i przekazywane w niej wartości. Księża Władysław Makowiec i Władysław Kłapkowski oraz siostra Amata Kossowska zaniepokojeni przenikaniem do niej elementów niekatolickiej filozofii czy obcych ideałów, apelowali do nauczycieli języka polskiego, na których w dużym stopniu spoczywa odpowiedzialność za wychowanie narodowe młodzieży, aby w doborze literatury uwzględniali nie tylko walory literackie, ale również wartości moralne ${ }^{91}$.

Ukazując wartość nauki religii w zakresie wychowania obywatelskiego, a szczególnie obywatelsko-państwowego, powoływano się na list pasterski kardynała Prymasa Augusta Hlonda O chrześcijańskie zasady życia państwowego z 23 kwietnia 1932 r., w którego III części odnajdywano katolicki program wychowania państwowego. Odwoływano się głównie do opisywanej przez Hlonda katolickiej karności obywatelskiej ${ }^{92}$, który zaznaczał, iż: „na czoło [...] powinności obywatelskich wysuwa się posłuszeństwo i szacunek, zasadzające się na prawie przyrodzonym, z którego władza państwowa bierze swój początek. Katolik jest obowiązany zachowywać należyty stosunek do prawowitej władzy bez względu na to, w czyim ręku władza spoczywa. Wolno atoli i należy ubiegać się w drodze legalnej o rządy uczciwe i katolickie. $Z$ drugiej strony przedstawiciele władzy państwowej powinni tak w sposobie rządzenia, jak i w życiu swoim wykazywać

\footnotetext{
${ }^{89}$ Tamże, s. 277.

${ }^{90}$ A. P[echnik], W sprawie reformy naszego szkolnictwa (Dokończenie), MWiK 1919, z. 8, s. $221-223$.

${ }^{91}$ W. M a k o w i e c, Grono nauczycielskie szkoły, MKiW 1918, z. 5-6, s. 213-217; W. Kła pk o w s k i, Literatura dla dzieci i młodzieży, MKiW 1925, z. 10, s. 443-448; A. K o s s o w s k a, Wpływ literatury współczesnej na młodzież, MKiW 1926, z. 7, s. 136-144.

${ }_{92}$ Z. C h or o m ań s ki, Wychowanie..., s. 35.
} 
poczucie władzy, wywodzącej się od Boga. Jakaż godność opromienia ich rządy, gdy w sposobie pojmowania i wykonywania przez nich władzy zaznacza się świadomość padającego na nich odblasku autorytetu Bożego!"93. Wielu przedstawicieli pedagogiki katolickiej i katechetów-wychowawców podzielało ten pogląd, zaznaczając w swych rozważaniach teoretycznych czy praktycznych działaniach, iż najwyższą normą w ujęciu zagadnienia wychowania państwowego są słowa Chrystusa: „Oddajcie co jest cesarskiego cesarzowi, a co jest Boskiego Bogu” (Mt 22, 21 $)^{94}$. Zasadę tę rozwinął w swoich rozważaniach m.in. ks. A. Gerstmann, który przypominał, iż dewizę tę głosił Jezus w czasach, kiedy skrajny nacjonalizm żydowski uważał każde świadczenie na rzecz państwa za zdradę ${ }^{95}$.

Autorzy artykułów „Miesięcznika Katechetycznego i Wychowawczego” zgadzali się również z opinią A. Hlonda, który zauważał przy tym, że jest to możliwe wówczas, gdy państwowość jest zdrowa, co w jego rozumieniu odnosiło się do „uznania autorytetu Bożego nad narodami i państwami”’6, a także wskazywał, iż z owego posłuszeństwa i szacunku wobec prawowitej władzy państwowej wypływa podporządkowanie się prawu i rozporządzeniom państwowym, ale jedynie tym, które są sprawiedliwe. Wynika to jego zdaniem z faktu, że „ustawa czy rozporządzenie nie stają się etyczne i sprawiedliwe przez to tylko, że je uchwalają i wydają ciała ustawodawcze lub władze do tego powołane. Jeżeli bowiem nie mają na celu rzeczywistych potrzeb Państwa i dobra ogólnego, jeżeli gwałcą przyrodzone prawa jednostek i rodzin, jeżeli wkraczają w prawa Kościoła, a nawet sprzeciwiają się prawu Bożemu, to mimo, że powstają w sposób prawem przewidziany, są nieetyczne i niesprawiedliwe" ${ }^{\prime 7}$. Zauważał przy tym, do czego odwoływało się wielu ówczesnych pedagogów katolickich (m.in. ks. A. Gerstmann ${ }^{98}$ ), iż w obliczu wszechwładzy państwowej należy przeciwstawiać się takim posunięciom, kierując się zasadą św. Piotra, iż „więcej należy słuchać Boga, aniżeli ludzi”’9.

Za kard. Hlondem, zaznaczano także, że katolik musi wprowadzać ideały etyki chrześcijańskiej we wszystkie dziedziny życia państwowego, dlatego „katolik obywatel, robotnik, urzędnik, oficer, żołnierz, poseł, senator, członek rządu nie może mieć dwu sumień, katolickiego dla życia prywatnego, a niekatolickiego dla spraw publicznych" ${ }^{100}$. Wynika to z faktu, iż „prawo Chrystusowe obowiązuje we wszystkich dziedzinach"101.

Podzielano również stanowisko Prymasa, zgodnie z którym wychowanie państwowe, przeniknięte zasadami etyki chrześcijańskiej, może służyć zwalczaniu,

${ }^{93}$ Cyt. za: tamże, s. 35-36.

${ }^{94}$ J. G r o c h o c k i, Nauka religii..., s. 7; A. G e r s t m a n n, O wychowaniu..., s. 219.

${ }^{95}$ A. Gerstm a n n, O wychowaniu..., s. 219-220.

${ }^{96}$ Cyt. za: Z. C h o r o m a ń s k i, Wychowanie..., s. 36.

${ }^{97}$ Cyt. za: tamże.

${ }_{98}^{98}$ A. G e r s t m a n n, O wychowaniu..., s. 220.

99 Z. C h o r o m a ń s k i, Wychowanie..., s. 36.

100 Cyt. za: tamże, s. 37.

101 Cyt. za: tamże. 
obecnego w życiu publicznym, „zdziczenia politycznego”, nienawiści, „która dzieli obywateli Państwa na nieprzejednane obozy, postępuje z przeciwnikami politycznymi jak z ludźmi złej woli, poniewiera ich bez względu na godność człowieczą i narodową, zniesławia i ubija moralnie"102.

Z analizy artykułów przedstawicieli pedagogiki katolickiej, zamieszczających swoje teksty na łamach „Miesięcznika Katechetycznego i Wychowawczego", wynika, iż popierają oni jedynie wychowanie obywatelskie, przeniknięte etyką katolicką. Niejednokrotnie, powołując się na encyklikę Piusa $\mathrm{XI}^{103}$, przekonywali: „Ci co powiadają, że nauka Chrystusa jest wrogą państwu, niechże dadzą takich żołnierzy, jakimi każe im być nauka Chrystusa; niech dadzą takich poddanych, takich małżonków, takie żony, takich rodziców, takich synów, takich panów, takie sługi, takich królów, takich sędziów, takich wreszcie urzędników skarbowych i płatników państwa, jakimi nakazuje być chrześcijańska nauka, a wtedy niechże sobie mówią, że jest ona wrogą rzeczpospolitej; przeciwnie, niech się nie wahają nazwać jej silną ostoją państwa, jeśli znajduje posłuch"104.

Respektowali oni zarówno wychowanie narodowe, jak i państwowe pod pewnymi jednak warunkami. W zakresie wychowania narodowego obcy duchowi pedagogiki katolickiej był zarówno internacjonalizm komunizmu, jak i pacyfizm ${ }^{105}$. Podkreślano, że naród to nie tylko wspólnota jednej ziemi, krwi, warunków gospodarczych, ale to przede wszystkim wspólnota kultury, w której elementami składowymi są język, religia i ciągłość historyczna w kontekście przeżywania duchowych wartości. W ich ujęciu naród to także tworzywo praw natury, co w rozumieniu pedagogiki katolickiej odnosiło się do praw Boga jako twórcy natury. Zaznaczano też, że wprawdzie naród nie może w sposób odrębny bytować poza jednostkami, to mimo wszystko wspólnota narodowa i świadomość indywidualności narodu jest rzeczywistością, która łączy jednostki w narodzie, łączy przeszłość ze współczesnością i wywiera wpływ na przyszłość. Naród jednak postrzegany był jako dobro względne, które musi być podporządkowane dobru bezwzględnemu, a więc Bogu i z uwagi na to służba dla narodu, to w ujęciu pedagogiki katolickiej służba znajdująca się w kręgu działań ludzkich skierowanych ku Bogu, czyli służba Bogu'106.

Wobec tak pojmowanego przez pedagogikę katolicką pojęcia narodu mieścił się ogólnie przyjęty obowiązek wychowania obywateli miłujących Ojczyznę aż po złożenie za nią ofiary z doczesnego życia, a więc ludzi dzielnych, odpowiedzialnych, pełnych honoru, ducha obowiązku i poczucia misji dziejowej ${ }^{107}$. W obliczu zaś traktowania narodu jako dobra względnego postulowano w wychowaniu nacjonalizm chrześcijański, pojmowany jako pokorę narodową, czyli „czerpanie natchnień z Najwyższego Ideału - Boga i [...] szerzenie Królestwa Bożego przez zdrową, swoistą, schrystianizowaną kulturę narodową"108.

\footnotetext{
102 Cyt. za: tamże.

103 Z. C h o r o m a ń s k i, Wychowanie państwowe, MKiW 1933, z. 1, s. 38.

104 Cyt. za: P i u s XI, Divini..., n. 53.

105 W. G r a n a t, Zasady pedagogii katolickiej..., s. 46.

106 Tamże, s. 47.

107 Tamże, s. 47-48.

108 Tamże, s. 47.
} 
Przedstawiciele pedagogiki katolickiej mieli też pozytywny stosunek do wychowania państwowego. Zauważali, że jest ono potrzebne i uzasadnione, ponieważ „nie naród jest wykonawcą władzy, lecz państwo”109. Niektórzy podkreślali, iż spór o to, czy wychowanie ma być „państwowe”, „obywatelskie” czy „,narodowe", to skutek nieporozumienia, ponieważ problem wychowania narodowego czy państwowego jest zasadny jedynie dla narodu, który nie ma państwa. Ich zdaniem wynika on być może z faktu identyfikacji pojęcia wychowania państwowego z wychowaniem prorządowym. Właściwe zaś pojmowanie wychowania państwowego musi brać pod uwagę, że jedynie stałym elementem tego wychowania jest państwo, Ojczyzna, zaś rząd jest z natury rzeczy zmienny. Tak rozumiane i praktykowane wychowanie państwowe, wzbogacone wyeksponowaną wcześniej etyką chrześcijańską, spotkało się z przychylnością przedstawicieli Kościoła i pedagogiki chrześcijańskiej ${ }^{110}$.

Zgadzali się więc oni z przyjęciem państwa jako najdoskonalszej formy społeczeństwa w porządku przyrodzonym oraz żądaniem z jego strony podporządkowania się obywateli jego prawom oraz poniesienia na jego rzecz ofiary mienia czy życia. Nie uznawali jednak Państwa lub narodu za najwyższe dobro lub ostateczny cel życia człowieka, gdyż ubóstwienie czegokolwiek, w tym również Państwa czy narodu traktowali jako doktrynę niechrześcijańską ${ }^{111}$. Dlatego też podkreślali, że w wychowaniu obywatelskim należy pamiętać, iż "nie obywatel jest dla państwa, ale państwo dla obywatela”. Stąd też państwo ma „obowiązek zabezpieczyć wszystkim swym obywatelom ich zasadnicze prawa do życia, mienia, spokoju, honoru i ma umożliwić i ułatwić urzeczywistnienie ich celu moralnego"112.

\section{Zakończenie}

Ks. W. Granat podkreślał, iż celem najwyższym wychowania katolickiego jest wieczne uczestnictwo w życiu Bożym człowieka odkupionego przez Chrystusa. Drogą zaś wiodącą do tego celu jest Chrystus ${ }^{113}$. Wobec czego - jak pisał Pius $\mathrm{XI}$ - „właściwym i bezpośrednim celem chrześcijańskiego wychowania jest współdziałać z łaską Bożą w urabianiu prawdziwego i doskonałego chrześcijanina, tj. samego Chrystusa w ludziach, przez chrzest odrodzonych"114. Pedagodzy katoliccy Drugiej Rzeczypospolitej zaznaczali, iż chrześcijańskie wychowanie nie ogranicza się jednak do człowieka, który w swych najgłębszych tęsknotach religijnych sięga jedynie daleko poza istnienie ziemskie. Chrześcijanin, w ich ujęciu, to jednocześnie człowiek doczesności i korzystający z jej dóbr. Stąd też

\footnotetext{
109 S. A b t, Wychowanie religijne na tle ruchu pedagogicznego, MKiW 1932, z. 6-7, s. 277.

110 A. Gers tm a n n, O wychowaniu..., s. 217-218.

111 Tamże, s. 219.

112 Tamże.

${ }^{113}$ W. G r a n a t, Zasady pedagogii katolickiej..., s. 51-52.

114 P i u s XI, Divini..., n. 94.
} 
celem chrześcijańskiego wychowania jest obowiązek złączenia i zharmonizowania wychowania duchowego $z$ fizycznym, intelektualnego $z$ moralnym oraz indywidualnego ze społeczno-narodowym, państwowym i ogólnoludzkim ${ }^{115}$.

Ta świadomość celu sprawiała, że w pedagogice katolickiej dwudziestolecia międzywojennego wartości, które miały być osiągane na drodze wychowania układały się w pewnego rodzaju „drabinę hierarchii”, na której szczycie znajdowało się Najwyższe Dobro - Bóg i złączona z Nim osobowość człowieka stworzonego do nieśmiertelności ${ }^{116}$. Ta zasada odnosiła się również do wychowania obywatelskiego, w kontekście którego pedagogia katolicka stawiała wprawdzie „dobro zbiorowości przed dobrem doczesnym jednostki, która w niektórych wypadkach ma nawet obowiązek życie doczesne poświęcić dla narodu"117, ale przypominała jednocześnie, że „wszystkie dobra doczesne niszczeją - giną państwa i narody, które tylko w znaczeniu przenośnym są nieśmiertelne, a dusza ludzka zawsze będzie żyła i na końcu wieków nawet z ciałem się złączy"118.

Personalizm katolicki Drugiej Rzeczypospolitej, podkreślając więc bardzo mocno wartość człowieka i jego godność jako dziecka Bożego, dla którego Chrystus (Bóg-Człowiek) przyszedł na świat, ustanowił Kościół i środki zbawienia, odrzucał stanowczo pogląd, że człowiek żyje jedynie „przez państwo i dla państwa, przez naród i tylko dla narodu, przez rasę i tylko dla potęgi rasy"119. Trudno jednak zgodzić się z Feliksem Araszkiewiczem, w kontekście przywołanych wcześniej racji, że „nurt katolicki w teleologii wychowawczej był nurtem najbardziej arealistycznym, [...] że siły, które reprezentował, najmniej kierowały się polską racją stanu i dobrem Rzeczypospolitej. Pedagogiki katolickiej [zaś - A. Z.] nie interesował człowiek jako członek określonej wspólnoty narodowej i państwowej. [...] Dlatego jej ideał wychowawczy [...] był nie do przyjęcia dla kierunków, które na wychowanie patrzyły przez pryzmat idei narodowej lub państwowej, bądź łącznie przez obie te idee"120. Ta ostra ocena wynikała być może z faktu, iż Kościół podejmował niejednokrotnie walkę z przerostami niektórych ideałów, które pragnęły usunąć albo obniżyć powagę kultu religijnego i stać się namiastką religii. Nigdy natomiast, jak pisał ks. W. Granat, Kościół nie występował „przeciw wychowaniu narodowemu, lecz przeciw skrajnemu szowinistycznemu nacjonalizmowi, który widzi naród, a nie widzi człowieka i ludzkości” ${ }^{21}$. Podkreślał on również, iż „Kościół uważa za obowiązek wychowanie państwowe, nie zgodzi się jednak na ubóstwienie państwa"122.

\footnotetext{
115 W. G ra n a t, Zasady pedagogii katolickiej..., s. 52.

116 Tamże.

117 Tamże, s. 53.

118 Tamże, s. 52.

119 Tamże, s. 35.

120 F. A r a s z k i e w i c z, Ideały wychowawcze..., s. 263.

121 W. G r a n a t, Katolicki..., z. 10, s. 428.

122 Tamże.
} 